\title{
GENÇLIK \\ HEDONIZM VE DIN (Z Kuşağı Örneği)
}

\author{
Yazar \\ Dr. Fatma Nur ŞENGÜL
}




\section{(C) Copyright 2021}

Bu kitabın, basım, yayın ve satış haklar Akademisyen Kitabevi A.Ş.'ne aittir. Anılan kuruluşun izni alınmadan kitabın tümü ya da bölümleri mekanik, elektronik, fotokopi, manyetik kağıt ve/veya başka yöntemlerle çoğaltılamaz, basılamaz, dağıtılamaz. Tablo, şekil ve grafikler izin alınmadan, ticari amaçlı kullanılamaz. Bu kitap T.C. Kültür Bakanlı̆̆ı bandrolü ile satılmaktadır.

ISBN

978-625-7401-44-9

Kitap Adı

Gençlik Hedonizm ve Din (Z Kuşağı Örneği)

Yazar

Fatma Nur ŞENGÜL

ORCİD iD: 000-0002-2995-943X

Yayın Koordinatörü

Yasin DİLMEN

Sayfa ve Kapak Tasarımı

Akademisyen Dizgi Ünitesi

Yayıncı Sertifika No

47518

Baskı ve Cilt

Vadi Matbaacılık

Bisac Code

REL000000

DOI

$\mathrm{xxx}$

\section{GENEL DAĞITIM}

Akademisyen Kitabevi A.Ş.

Halk Sokak 5 / A

Yenişehir / Ankara

Tel: o312 4311633

siparis@akademisyen.com 


\section{ÖNSÖZ}

Çalışmamızda din ile hedonizm gençler evreni üzerinden ele alınmaktadır. Din olgusu insanlık tarihinin var olduğu andan itibaren hem bireysel anlamda hem de toplumsal anlamda sürekli tartışılan bir gerçeklik olarak varlık sürmektedir. Bireylerin hayatlarında var olan din ya da kutsal olan, onların eylemlerini, duygularını, hayata bakış açlarını olumlu ya da olumsuz etkileyebilmektedir. Hedonizm ise Antik Çağda ortaya çıkan günümüz dünyasında kapitalizm ve tüketim toplumunun getirdikleri ile görünürlüğü artan, kişiyi hazza sevk eden bir anlayış olarak günümüz gençliği üzerinde etkili olduğu düşünülen bir olgudur. Günümüz gençliğinin sergilemiş olduğu hedonizm eğilimi bu çalışmanın konusunun seçilmesinde etkili bir faktör olmuştur. Seçilen bu konu kapsamında dini tutum ölçeği bulma hususunda zorluk çekilmemiştir ancak hedonizm ölçeğinin olmaması yeni bir ölçek geliştirme ihtiyacını doğurmuştur. Bu minvalde bir hedonizm ölçeği geliştirilmiştir ve çalışmamızda kullanılmıştır. Saha çalışmasına başlandığı sırada Covid-19 hastalığının dünya genelinde pandemiye dönüşmesi çalışmanın yapılmasında güçlük oluşturmuştur. Bu yüzden saha çalışmasında online anket sisteminden yararlanılmış ve Türkiye genelinde bulunan hem devlet hem de vakıf üniversitelerine anket formu online olarak gönderilmiştir.

Araştırma giriş, iki ana bölüm ve sonuçtan meydana gelmektedir. Giriş kısmında araştırmanın konusu, önemi, amacı hipotezleri, yöntemleri ve sınırlılıkları hakkında bilgi verilmektedir. Birinci bölüm birbiri ile ilişkili üç kısımdan meydana gelmektedir. Birinci kısımda hedonizmin tarihsel ve kuramsal gelişimi, ikinci kısımda dini tutum ve dindarlığın sosyolojik anlamları ve üçüncü kısımda gençlik tanımlamaları ve tipolojileri ele alınmaktadır. İkinci bölümde sahadan gelen veriler sosyolojik bakış açısıyla ele alınıp, analiz edilmektedir. Sonuç kısmında ise araştırma verilerinin değerlendirilmesine, hipotezlerin testine ve konu ile ilgili önerilere yer verilmektedir.

Araştırma sürecinde pek çok kişinin katkı ve desteği söz konusu olmuştur. Öncelikle danışmanlığının ilk anından itibaren bilgi, tecrübe ve ilmi duruşu ile her konuda bana destek olan, çalışmanın en başından sonuna kadar titizlik ile çalışmamı takip eden danışmanım Prof. Dr. Halil Aydınalp hocama teşekkürlerimi sunarım. Yine aynı şekilde akademi hayatıma ilk adım attığım andan itibaren beni destekleyen, gelmiş olduğum noktada büyük emekleri olan Prof. Dr. Özcan GÜNGÖR hocama, destekleyici ve teşvik edici kişiliği sebebi ile teşekkür ederim. 
Ayrıca çalışma konusu hakkında bana fikir veren Prof. Dr. Zeki Arslantürk hocama bana ayırmış olduğu vakitlerden ve her zaman yanımda bir aile gibi duruşundan ötürü teşekkür ederim. Saha çalışması sırasında beni destekleyen babam Dr. Öğr. Üyesi Halil Şengül, eşim Mehmet Fazıl Şengül ve İstanbul Aydın Üniversitesi sosyoloji bölümü öğretim üyelerine teşekkürlerimi sunarım. Bu süreçte fedakârlıkların ve katkıların en büyügünü gösteren, sabır ve hoşgörüleri ile bana katlanmak zorunda kalan eşim Mehmet Fazıl Şengül'e ve kızım Rüveyda Şengül'e ayrıca tekrar teşekkür ederim. Son olarak eğitim hayatımın ilk yıllarından itibaren bana destek verip, dua eden aileme ve kuzenim Arzu Keçici'ye yürekten şükranlarımı sunarım.

Gayret ve çalışma bizden takdir Allah’tandır. Herkes için faydalı bir çalışma olmasi temennisiyle...

Dr. Fatma Nur ŞENGÜL fnyilmaz@aydin.edu.tr İstanbul, 2021 


\section{İÇiNDEKILER}

GíRiş 1

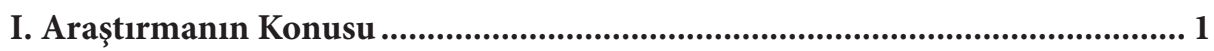

II. Araştırmanın Amaci............................................................................................ 5

III. Araştırmanın Hipotezleri ................................................................................... 6

IV. Araştırmanın Kapsam ve Sınırları ....................................................................... 9

V. Araştırmanın Modeli ve Yöntemi .................................................................... 10

VI. Ölçek Formunun Hazırlanması, Dağıtılması ve Toplanması ........................ 11

VII. Verilerin Analizinde Kullanılan Yöntemler ................................................. 12

\section{BÖLÜM}

ARAŞTIRMANIN KAVRAMSAL VE KURAMSAL ÇERÇEVESI ..............................13

1. HEDONIZM: KAVRAM, TARIH VE TEORİ............................................... 13

1.1. Ahlak Felsefesinde "En Yüksek İyi" ............................................................................. 13

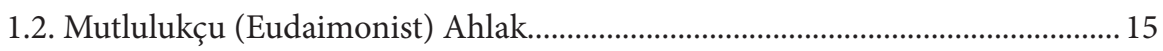

1.3. Hazcllk (Hedonizm) ........................................................................................... 17

1.3.1. Ahlaki ve Psikolojik Hedonizm ................................................................... 20

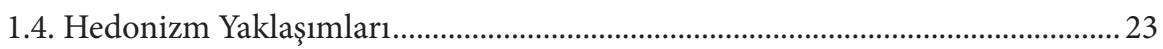

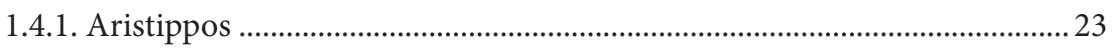

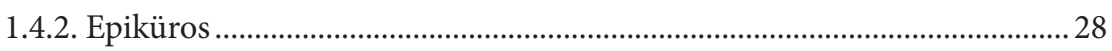

1.5. Hedonizmin Gelişimi: Faydacılık (Ütilitarizm) ....................................................... 32

1.6. Faydacı Yaklaşımlar …………………………………………………………........ 34

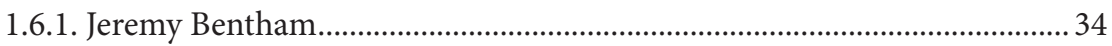

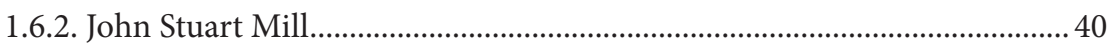

1.6.3. George Edward Moore ............................................................................. 43

1.7. İslam Ahlak Felsefesinde Hedonizm .................................................................. 44

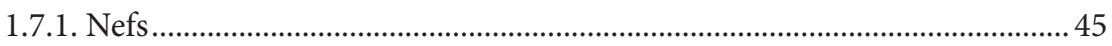

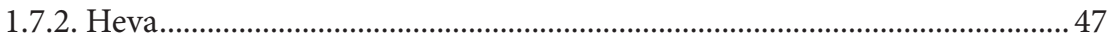

1.8. İslam Ahlak Filozoflarının Hedonizm Yaklaşımları................................................. 49

1.8.1. Ebu Bekir er-Razi’nin Haz ve Elem Öğretisi ............................................... 49

1.8.2. Farabi’nin Haz ve Elem Öğretisi ................................................................. 52

1.8.3. İbn Miskeveyh'de Haz ve Ac1.................................................................... 55

1.9. Günümüz Hedonizmine Zemin Hazırlayan Süreçler ...........................................59

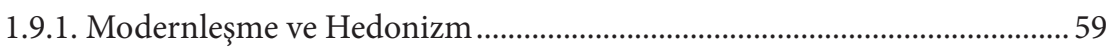

1.9.2. Kapitalizm ve Hedonizm ............................................................................... 64

1.9.3. Tüketim, Tüketim Toplumu ve Hedonizm.................................................... 70

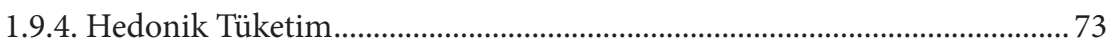




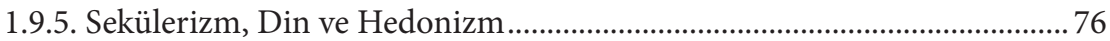

1.9.6. Sanayileşme Sonrası Toplum ve Pop Hedonizm ............................................ 82

2. DİNIN/DINNDARLIĞIN SOSYOLOJIKK ANLAMLARI ................................... 84

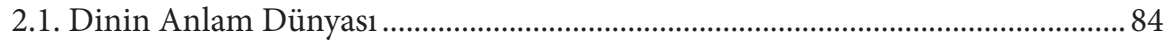

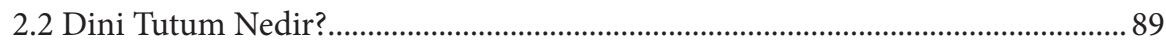

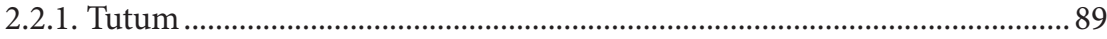

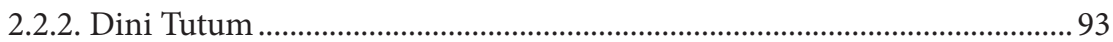

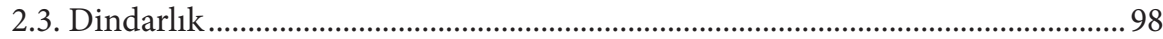

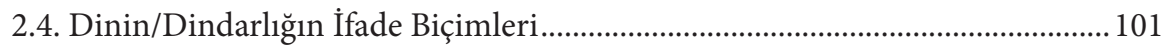

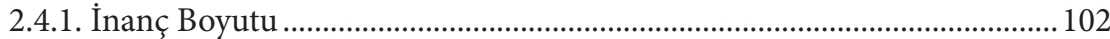

2.4.2. İbadet Boyutu.............................................................................................. 104

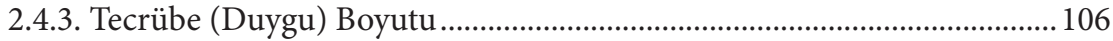

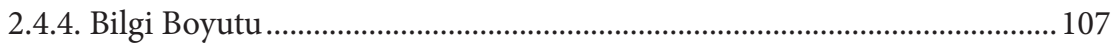

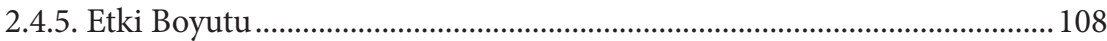

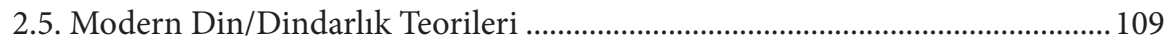

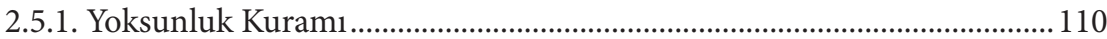

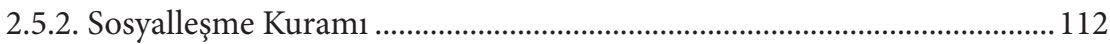

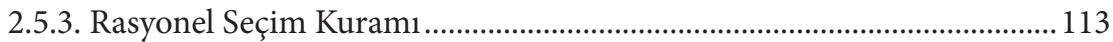

2.5.4. Anlam ve Aidiyet Arayışı Olarak Din........................................................ 115

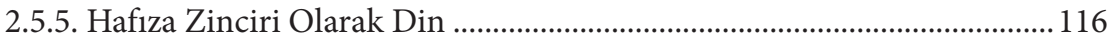

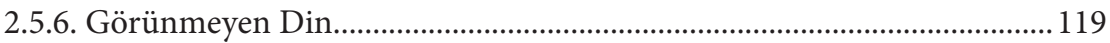

2.5.7. İnanmadan Ait Olma - Ait Olmadan İnanma ........................................ 121

3. GENÇLİK, DİN VE HEDONIZZM.............................................................. 124

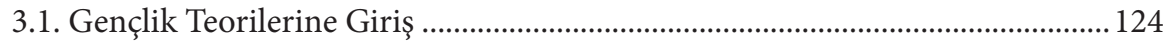

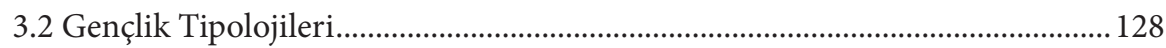

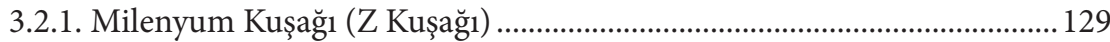

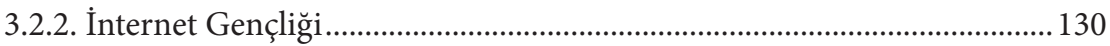

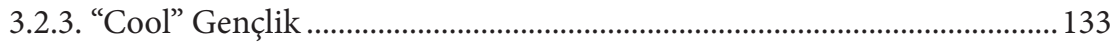

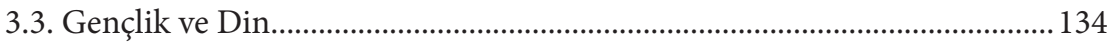

3.4. Gençlik ve Haz ....................................................................................................... 140

2.BÖLÜM

UYGULAMALI BIR ARAŞTIRMA GENÇLERDE DİNI

TUTUM VE HEDONIZM............................................................ 143

4. Gençlerde Dini Tutum ve Hedonizm İlişkisini Ölçmeye Yönelik Bir

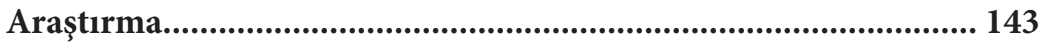

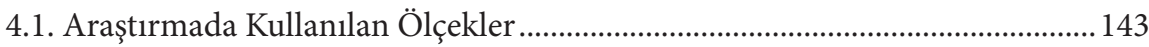

4.1.1. Ok-Dini Tutum Ölçeği................................................................................... 143

4.1.2. Hedonizm Ölçeği Geçerlik ve Güvenirlik Çalışması .................................. 145 
4.2. Araştırmaya Katılanların Sosyal Kimliği ............................................................... 151

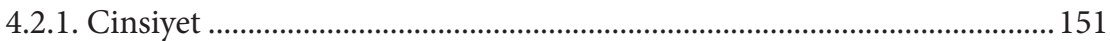

4.2.2. Yaş Aralı̆̆

4.2.3. Mezun Olunan Lise Türü................................................................................. 152

4.2.4. Eğitim Görülen Üniversitenin Türü............................................................. 154

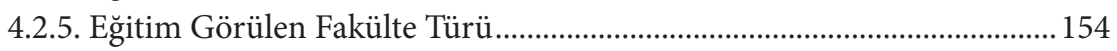

4.2.6. Hayatın Büyük Çoğunun Geçirildiğgi Yer .................................................. 156

4.2.7. Aylık Yapılan Harcama Miktarı ................................................................ 157

4.2.8. Ailelerin Aylık Ortalama Gelir Düzeyleri ................................................ 158

4.2.9. Gençlerin Modernlik-Geleneksellik Ekseninde

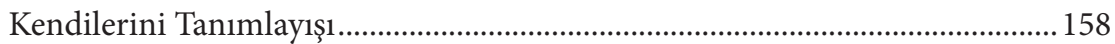

4.2.10. Gençlerin Sahip Oldukları Boş Vakit Süresi ............................................. 160

4.2.11. Serbest Zaman Aktiviteleri.......................................................................... 161

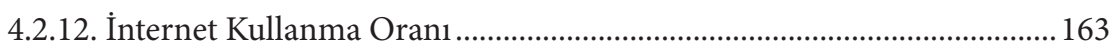

4.3. Araştırmaya Katılanların Dindarlık/Dini Tutumunun Tasviri .......................... 165

4.3.1. Dini Tutumun Alt Boyutlarının Tasviri................................................... 170

4.4. Araştırmaya Katılanların Hedonizm Eğiliminin Tasviri ................................... 173

4.4.1. Hedonizm Ölçeğinin Alt Boyutlarının Tasviri .......................................... 181

4.5. Araştırmaya Katılanların Sosyal Kimliklerine Göre

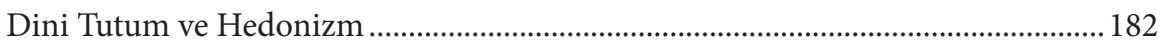

4.5.1. Cinsiyete Göre Dini Tutum ve Hedonizm................................................. 182

4.5.2. Yaş Aralığına göre Dini Tutum ve Hedonizm............................................. 186

4.5.3. Mezun Olunan Lise Türüne Göre Dini Tutum ve Hedonizm .................. 188

4.5.3. Eğitim Görülen Üniversite Türüne Göre Dini Tutum ve Hedonizm ..... 190

4.5.5. Hayatın Büyük Çoğunun Geçtiği Yere Göre

Dini Tutum ve Hedonizm ....................................................................................... 193

4.5.6. Aylık Yapılan Harcama Miktarına Göre

Dini Tutum ve Hedonizm ..................................................................................... 196

4.5.7. Ailenin Aylık Gelir Ortalamasına Göre

Dini Tutum ve Hedonizm ...................................................................................... 197

4.5.8. Geleneksellik-Modernlik Eksenine Göre

Dini Tutum ve Hedonizm .................................................................................... 199

4.6. Araştırmaya Katılanların Dini Tutum ve Hedonizm İlişkisi..............................203

4.6.1. Dini Tutum ve Hedonizm İlişkisi .................................................................203

4.6.2. Dini Tutum ile Hedonizm Alt Boyutlarının İlişkisi ....................................204

4.6.3. Hedonizm ile Dini Tutum Alt Boyutlarının İlişkisi ...................................206

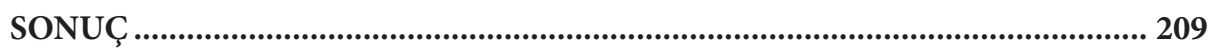

Ek.1. Anket-Ölçek Formu .......................................................................219

KAYNAKLAR ..................................................................................... 225 



\section{KISALTMALAR}

ABD :

Amerika Birleşik Devletleri

ARPA :

Gelişmiş Savunma Araştırmaları Projeleri

Birimi

ARPANET :

Gelişmiş Araştırma Projeleri Dairesi Ağ1

Bkz. :

Bakınız

C. :

Cilt

Çev. :

Çeviren

Der. :

Derleyen

Ed. :

Editör

Hz. :

Hazretleri

İ.Ö. :

İsa'dan Önce

İ.S. :

İsa'dan Sonra

LGS :

Liselere Geçiş Sınavı

M.Ö. :

Milattan Önce

M.S. :

Milattan Sonra

Ok- Dini Tutum Ölçeği : Üzeyir Ok Tarafından Geliştirilen Dini Tutum Ölçeği

SEKAM :

Sosyal Ekonomik ve Kültürel Araştırmalar Merkezi

SETA :

SPSS :

TGSP :

TÜIK :

YKS :

yy. :

Siyaset, Ekonomi ve Toplum Araştırmaları Vakfı

Sosyal Bilimciler İçin İstatistik Programı

Türkiye Gençlik STK'ları Platformu

Türkiye İstatistik Kurumu

Yüksek Öğrenime Geçiş Sınavı

Yüzyıl 



\section{KAYNAKLAR}

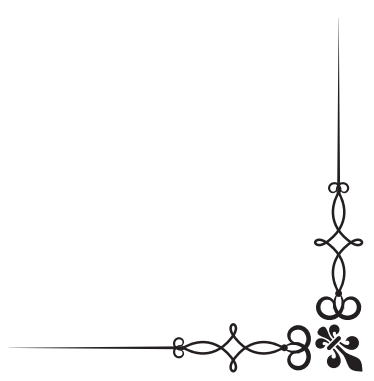

Adorno, W. T. ve Horkheimer M. (2010). Aydınlanmanın Diyalektiği, N. Ülner ve E. Ö. Karadoğan (çev.), İstanbul: Kabalcı Yayınevi.

Afşar, T. (2004). Felsefe Sözlüğ̈̈. İstanbul: Bulut Yayınları.

Akarsu, B. (1970). Mutluluk Ahlakı. İstanbul: İnkılap Yayınları.

Akgül, A. ve Çevik, O. (2003). İstatistiksel Analiz Teknikleri, SPSS’te İsletme Yönetimi Uygulamaları. Ankara: Emek Ofset Yayınevi.

Akyüz, İ. (2014). Türkiye'de Gençlik, Din ve Değerler Konusunda Yapılan Ampirik Araştırmaların Yöntem ve İçerik Analizi. Sakarya Üniversitesi İlahiyat Fakültesi Dergisi. Cilt:17, Say1:30, 1-28.

Akyüz, N. ve Çapçığlu, İ. (2013). Din Sosyolojisinin Doğuşu ve Gelişimi. N. Akyüz ve İ. Çapçıŏlu (Ed.). Din Sosyolojisi içinde. Ankara: Grafiker Yayınları, 2013, 73-102.

Akyüz, N. ve Çapçığlu, İ. (2013). Dini Tecrübenin İfade Şekilleri. N. Akyüz ve İ. Çapçığlu (Ed.). Din Sosyolojisi içinde. Ankara: Grafiker Yayınları, 2013, 49-56.

Aldridge, A. (2015). Sekülerleşmenin Yükselişi: Dinin Toplumsal Önemini Kaybetmesi.

İ. Çapçığlu ve S. Yılmaz (çev). M. A. Kirman ve İ. Çapçığlu (Ed.). Sekülerleşme Klasik ve Çağdaş Yaklaşımlar içinde. Ankara: Otto, 2015, 75-118.

Allport, G. W. (1966). The Religious Context of Prejudice. Journal For the Scientific Study of Religion. Cilt:5, Say1 3, 447-457.

Althusser, L. (2014). İdeoloji ve Devletin İdeolojik Aygıtları. İstanbul: İthaki Yayınları.

Altıntaş, R. (2005). Din ve Sekülerleşme. İstanbul: Pınar Yayınları.

Altunışık, R., Coşkun, R., ve Yıldırım, E. (2002). Sosyal Bilimlerde Araştırma Yöntemleri. Sakarya: Sakarya Kitapevi.

Amman, M. T. (2010). Türkiye'de Ailenin Açık ve Örtülü Sekülerleşmesinin Sosyolojik Analizi. M. F. Bayraktar (Ed.). Aile ve Eğitim içinde. İstanbul: Ensar Neşriyat, 2010, 41-70.

Arisoy, Ö. (2009). Internet Addiction and Its Treatment. Current Approaches In Psychiatry, No :1, 54-68.

Aron, R. (2007). Sosyolojik Düşüncenin Evreleri. İstanbul: Kırmızı Yayınları. 
Arslan, A. (2006a). İlkçağ Felsefe Tarihi I, Sokrates Öncesi Yunan Felsefesi. İstanbul: İstanbul Bilgi Üniversitesi Yayınları.

Arslan, A. (2006b). İlkçă̆ Felsefe Tarihi II, Sofistlerden Platon’a. İstanbul: İstanbul Bilgi Üniversitesi Yayınları.

Arslan, A. (2009). Felsefeye Giriş. Ankara: Adres Yayınları.

Arslantürk, Z. (1998). Kutsalın Dönüşü, Yeni Toplum Arayışları. İstanbul: Ayışığı Kitaplar1.

Arslantürk, Z. (2006). Dindarlığın Bağımsız Değişkenleri. H. Hökelekli (Ed.). Dindarlık Olgusu Sempozyum, Tebliğ ve Müzakereleri içinde. Bursa: Kurav Yayınları, 2006, 239-257.

Arslantürk, Z. (2011). Uygulamalı Sosyal Araştırma. İstanbul: Çamlıca Yayınları.

Arslantürk, Z. ve Amman, T. (2017). Sosyoloji, Giriş Kavramlar, Süreçler, Kurumlar, Teoriler. İstanbul: Çamlıca Yayınları.

Aslan, A. (2006). Heva Kavramı Üzerine Kur’an Perspektifinden Bir İnceleme. Süleyman Demirel Üniversitesi İlahiyat Fakültesi Dergisi. Sayı:17, 55-68.

Audi, R. (1999). The Cambridge Dictionary of Philosophy, Second Edition. New York: Cambridge University Press.

Aydın, İ. H. ve Bekiryazıcı, E. (?). İslam Ahlak esasları ve Felsefesi, İstanbul: Yenda Yayıncilik.

Aydınalp, H. (2018). Din ve Dünyevileşme: Kuzey Kıbrıs Örneği. İstanbul: Çamlıca Yayinlar1.

Aydınalp, H. (2019). Yerel Bir Dünyevileşme Kuramı: Özerk Dünyevileşmeler. M. A. Kirman ve V. Ertit (Ed). Sekülerleşme Tartışmaları içinde. Ankara: Kadim Yayınları, 2019, 153-196.

Baran, G. A. (2013). Genç ve Gençlik: Sosyolojik Bakış. Gençlik Araştırmaları Dergisi. Say1:1, Cilt:1. 6-26.

Batson, C. D. ve Ventis, J. L. (1982). The Religious Experience: A Socio-Psychological Perspective. Newyork : Oxford University Press.

Baudrillard, J. (2008). Tüketim Toplumu. H. Deliceçaylı ve F. Keskin (çev.), İstanbul: Ayrintı Yayınları.

Bauman, Z. (2012). Küreselleşme: Toplumsal Sonuçları. A. Yılmaz (çev.), İstanbul: Ayrıntı Yayınları.

Bayhan, V. (2011a). Tüketim Toplumunda Bireyin Ontolojik Mottosu “Tüketiyorum Öyleyse Varım". Sosyoloji Konferansları. Sayı: 43, 221-248.

Bayhan, V. (2011b). Hedonist ve Püritan Etik Sarmalında Postmodern Gençlik. Uluslararası Asya ve Kuzey Afrika Çalışmaları Kongresi Bildiri Kitabı içinde, Cilt:1, Ankara: Atatürk Kültür, Dil Tarih Yüksek Kurumu Yayınları, 195-206.

Bayhan, V. (2014). Milenyum veya (Y) Kuşağı Gençliğinin Sosyolojik Bağlamı. Gençlik Araştırmaları Dergisi. Yıl: 2, Cilt: 2, Sayı:3, 8-25.

Bayraktar, M. (2012). İslam Felsefesine Giriş. Ankara: Türkiye Diyanet Vakfı Yayınları. Bayyiğit, M. (1989). Üniversite Gençliğinin Dinî İnanç, Tutum ve Davranışları Üzerine Bir Araştırma. Yayımlanmamış doktora tezi. Bursa: Uludağ Üniversitesi Sosyal Bilimler Enstitüsü.

Bell, D. (1976). The Cultural Contradictions of Capitalism. New York: Basic Books, Inc. Bentham, J. (2017). Ahlak ve Yaşam İlkeleri. İstanbul: Litera Yayıncılık. 
Berger, P. L. (2002). Sekülerizmin Gerilemesi. A. Köse (Ed.). Sekülerizm Sorgulanıyor içinde. İstanbul : Ufuk Kitapları, 2002, 11-32.

Berger, P. L. (2015). Kutsal Şemsiye. A. Coşkun (çev.), İstanbul: Rağbet Yayınları.

Berkes, N. (2003). Türkiye'de Çağdaşlaşma, A. Kuyaş (Haz.), İstanbul: Yapı Kredi Yayınlari.

Bertrand, A. (2001). Ahlak Felsefesi. S. Zeki (çev.), Ankara: Akçă̆ Yayınları.

Birand, K. (1958). İlkçă̆ Felsefesi Tarihi. Ankara: Ajans-Türk Matbaası.

Bircan, H. H. (2001). İslam Felsefesinde Mutluluk. İstanbul: İz Yayıncılı.

Bocock, R. (2009). Tüketim. İ. Kutluk (çev.), Ankara: Dost Kitapevi.

Bozkurt, V. (2000). Püritanizmden Hedonizme Yeni Çalışma Etiği. Bursa: Alesta.

Bruce, W. (2015). Sekülerleşme: Sistematik Bir Betimleme. İ. Çapçığlu (çev.). M. A. Kirman ve İ. Çapçığlu (Ed.). Sekülerleşme Klasik ve Çağdaş Yaklaşımlar içinde. Ankara: Otto, 2015, 25-44.

Büyüköztürk, Ş. (2007). Sosyal Bilimler İçin Veri Analizi El Kitabı. Ankara: Pegem Yayincilik.

Can, A. (2016). SPSS ile Bilimsel Araştırma Sürecinde Nicel Veri Analizi. Ankara: Pegem Akademi Yayınları.

Cevizci, A. (1999). Felsefe Sözlüğ̈̈. İstanbul: Paradigma Yayınları.

Cevizci, A. (2018). Felsefe Tarihi. İstanbul: Say Yayınları.

Coşkun, T. (2019). Hedonik ve Faydacı Tüketim Davranışları ile Tüketici Etnosentrizmi Arasındaki İlişki: Kuşaklara Yönelik Bir Araştırma. Yayınlanmamış Doktora Tezi. Muğla: Muğla Sıtkı Koçman Üniversitesi Sosyal Bilimler Enstitüsü.

Cüceloğlu, D. (2007). İnsan ve Davranışı, Psikolojinin Temel Kavramları. İstanbul: Remzi Kitapevi.

Çağrıcı, M. (1998). Heva. TDV İslam Ansiklopedisi. Cilt: 17, Ankara: Türkiye Diyanet Vakfi Yayınları.

Çağrıc1, M. (2018). İslam Düşüncesinde Ahlak. İstanbul: Değerler Eğitimi Merkezi Yayınları.

Çapçığlu, İ (2013). Modernleşme. İ. Çapçıŏlu ve H. Beşerli (Ed.). Sosyolojiye Giriş içinde. Ankara: Grafiker yayınları, 2013, 289-315.

Çelikkol, A. K. (2010). Gelişimle İlgili Temel Kavramlar. H. Ergin ve A. Yıldız (Ed.). Gelişim Psikolojisi içinde. Ankara: Nobel Yayınları, 2010, 33-56.

Çetin, Ö. (2014). Din. M. Talas (Ed.). Sosyal Antropoloji içinde. İstanbul: Lisans Yayınc1lik, 2017, 141-161.

Çetinkaya, Y. (1992). Reklamcılık. Ankara: Ağaç Yayınları.

Çiğdem, A. (2011). Aydınlanma Düşüncesi. İstanbul: İletişim Yayınları.

Davie, G. (2005). Din Sosyolojisinde Yeni Yaklaşımlar: Batılı Bir Bakış. M. Akgül ve İ. Çapçığlu (çev.). Ankara Üniversitesi İlahiyat Fakültesi Dergisi. Sayı:1, 203-216.

Davie, G. (2015). Yeniden Kutsallaşma. İ. Toker (çev.). M. A. Kirman ve İ. Çapçığlu (Ed.). Sekülerleşme Klasik ve Çağdaş Yaklaşımlar içinde. Ankara: Otto Yayıncılık, 2015, 253-274.

Demir, Ö. ve Acar, M. (1997). Sosyal Bilimler Sözlüğü. Ankara: Vadi Yayınları.

Demirezen, İ. (2010). Tüketim Toplumun Oluşumu ve Din ile Etkileşimi. Din Bilimleri Akademik Araştırma Dergisi. Cilt: 10, Sayı: 3, 97-109.

Deniz, A. Ç. (2012). Eğitimli Gençliği Anlamada Yeni Bir Tipoloji Önerisi: Cool Gençlik. Uşak Üniversitesi Sosyal Bilimler Dergisi. Cilt:5, Sayı: 2, 115-139. 
Devellis, R. F. (2014). Ölçek Geliştirme Kuram ve Uygulamalar. T. Totan (Ed.). Ankara: Nobel Yayınları.

Durkheim, E. (1995). The Elemantary Forms Of Religious Life. (K. E. Fields Transleted), New York: The Free Press.

Eisenstadt, S. N. (1966). Modernization : Protest and Change. New Jersey : Englewood Cliffs.

Epikür. (1962). Mektuplar ve Maksimler. İstanbul: Remzi Kitapevi.

Ercan, İ. Ve Kan, İ. (2004). Ölçeklerde Güvenirlik ve Geçerlik. Uludă̆ Üniversitesi Tip Fakültesi Dergisi. Say1: 30 (3): 211-226.

Erkan, E. (2018). Gençler Tüketim ve Din. İstanbul: Hiper Yayın.

Ertit, V. (2014). Sekülerleşme: Dinden Uzaklaşmanın Hikâyesi. Ankara: Liberte Yayın Grubu.

Ertit, V. (2015). Endişeli Muhafazakârlar Çağı. Ankara: Liberte Yayın Grubu.

Eyüpoğlu, O. ve Yıldız, M. (2014). Kur'an ve Tarihsellik: Beşerî Eylemin Toplumsal Sınırı. On Dokuz Mayıs Üniversitesi İlahiyat Fakültesi Dergisi. Sayı: 37, 97-130.

Freyer, H. (2013). Din Sosyolojisi. T. Kalpsüz (çev.), Ankara: Doğu Batı Yayınları.

Frodov, İ. (1991). Felsefe Sözlü̈̆̈̈. A. Çalışlar (çev.), İstanbul: Cem Yayınevi.

Fromm, E. (1990). Psikanaliz ve Din. Ş. Algaput (çev.), İstanbul: Arıtan Yayınevi.

Furseth I. Ve Repstad P. (2011). Din Sosyolojisine Giriş, Klasik ve Çağdaş Yaklaşımlar. İ Çapçıŏlu ve H. Aydınalp (çev.), Ankara: Birleşik Yayınevi.

Giddens, A. ve Sutton, P. W. (2019). Sosyoloji. E. A. Kayhan (çev.). İstanbul: Kırmızı Yayinlar1.

Glock, Y. C. (1964). The Role of Deprivation in the Origin and Evolution of Religious. R. Lee and M. E. Marty (ed). Religion and Social Conflict içinde. New York: Oxford University Press, 1964, 24-36.

Glock, Y. C. (1998). Dindarlı̆̆ın Boyutları Üzerine. M. E. Köktaş (çev). Y. Aktay ve M. E. Köktaş (der). Din Sosyolojisi içinde. Ankara: Vadi Yayınları, 252-274.

Gökberk, M. (1996). Felsefe Tarihi. İstanbul: Remzi Kitapevi.

Günay, Ünver. (2017). Din Sosyolojisi. İstanbul: İnsan Yayınları.

Güney, S. (2012). Sosyal Psikoloji. Ankara: Nobel Yayıncilık

Güngör, Ö. (2016). Araf'taki Kimlik Alevilik Bektaşilik. Ankara: Sonçağ Yayınları.

Gür, B., Dalmış, İ., Kırmızıdağ, N., Çelik, Z., ve Boz, N. (2012). Türkiye’nin Gençlik Profili. Ankara: SETA Yayınları.

Habermas, J. (2002). Civil Society and Political Public Sphere. C. Calhoun (eds). Contemporaray Sociology Theory. Massachusetts: Blackwell Pub, 401-410.

Hançerlioğlu, O. (1977). Felsefe Ansiklopedisi, Kavramlar ve Akımlar Cilt: 2. İstanbul: Remzi Kitapevi.

Hançerlioğlu, O. (1995). Dört Bin Yıllık Düşünce, Sanat ve Bilim Tarihinin Klasik Yapıtla$r ı$ Üzerine Eleştirel İnceleme. İstanbul: Remzi Kitapevi.

Hedonizm Gençleri Bataklığa Sürüklüyor. (2018). Yeni Şafak Gazetesi. https://www.yenisafak.com/hayat/hedonizm-gencleri-batakliga-surukluyor-3399165 (Erişim Tarihi 03.12.2020).

Herriot, P. (2009). Religious Fundamentalism: Global, Local, Personal. London : Routledge.

Heyet. (2007). Kur'an-ı Kerim Açıklamalı Meali, Ankara: TDV Yayınları. 
Hökelekli, H. (2002). Gençlik ve Din. H. Hökelekli (Ed.). Gençlik ve Din içinde. Anakara: Ankara Okulu, 2002, 11-29.

İnanç, Y. B., Bilgin, M. ve Atıc1, K. M. (2015). Gelişim Psikolojisi: Çocuk ve Ergen Gelişimi, Ankara: Pegem Akademi.

Kağıtçıbaşı, Ç. (2017). Dünden Bugüne İnsan ve İnsanlar Sosyal Psikolojiye Giriş. İstanbul: Evrim Yayınevi.

Kara, M. (2010). Tasavvuf ve Tarikatlar Tarihi. İstanbul: Dergâh Yayınları.

Karaca, F. (2004). Din Psikolojisi. Trabzon: Eser Ofset Matbaacılık.

Karaca, M. (2007). İnternet Gençliği: Yeni Bir Gençlik Tiplemesi Denemesi. e-Journal of New World Sciences Academy. Cilt: 2, No: 4, 419-438.

Karaman H. (2013b). Ebu Bekir er-Razi: İlhadın Gölgesinde Bir Filozof. M. C. Kaya (Ed.). İslam Felsefesi Tarih ve Problemleri içinde. İstanbul: İsam Yayınları, 2013, 119144.

Karaman, H. (2013a). Ruh Sağhı̆g. İstanbul: İz Yayıncılık.

Karaman, H. (2018). İslam Ahlak Filozofları. M. S. Saruhan (Ed.). İslam Ahlak Esasları ve Felsefesi içinde. Ankara: Grafiker Yayınları, 2018, 159-182.

Karaman, H. ve diğerleri (2011). Kur'an-ı Kerim ve Açıklamalı Meali. Ankara: Türkiye Diyanet Vakfı Yayınları.

Karaşahin, H. (2013). Gençlik ve Din. N. Akyüz ve İ. Çapçığlu (Ed.). Din Sosyolojisi içinde. Ankara: Grafiker Yayınları, 2013, 237-252.

Karslı, N. (2017). Gençlerde Özsayg1- Dindarlık İlişkisi. Avrasya Sosyal ve Ekonomi Araştırmaları Dergisi. 16-46.

Kaya, H. (1998). Din Eğitiminde İletişim ve Dini Tutum. Samsun: Etüt Yayınları.

Kayıklık, H. (2006). Bireysel Dindarlığın Boyutları ve İnanç Davranış Etkileşimi. İslami Araştırmalar Dergisi. Cilt:19, Sayı:3, 491-499.

Kılıç, M. (2013). Gerçek Yaşam Tadında: Gelişim Dönemleri III: Yetişkinlik ve Yaşlılık. Ankara: Pegem Yayınları.

Kızılçelik ve Erjem, Y. (1996). Açıklamalı Sosyoloji Sözlüŭ̈̈̈. İzmir: Saray Kitapevleri.

Kirman, M. A. (2005). Din ve Sekülerleşme: Üniversite Gençliği Üzerine Sosyolojik Bir Araştırma. Adana: Karahan Kitapevi.

Kirman, M. A. (2010). Yeni Dini Hareketler Sosyolojisi. Ankara: Birleşik Yayınevi.

Kirman, M. A. (2016). Din Sosyolojisi Sözlü̈̆̈̈̈. Adana: Karahan Kitapevi.

Koç, M. (2005). Din Psikolojisi Araştırmalarında Ergenlik Dönemi Üzerine Türkçe Yapılan Çalışmalarla İlgili Bir Literatür İncelemesi. Sakarya Üniversitesi İlahiyat Fakültesi Dergisi, 12.

Koç, M. (2009). Demografik Özellikler ile Dindarlık Arasındaki İlişki: Yetişkinler Üzerine Ampirik Bir Araştırma. Uludă̆ Üniversitesi İlahiyat Fakültesi Dergisi. 1 (18), 473-493.

Kongar, E. (1995). Toplumsal Değişme Kuramları ve Türkiye Gerçeği. İstanbul: Remzi Kitapevi.

Koştaş, M. (1995). Üniversite Öğrencilerinde Dine Bakış. Ankara: Türkiye Diyanet Vakfı Yayınları.

Kökcü, H. (2019). Üniversite Öğrencilerinde Aile İçi Dini Aktiviteler Dini Tutum ve Yaşam Doyumu Arasındaki İlişki. Yayımlanmamış Yüksek Lisans Tezi. İstanbul: Zaim Üniversitesi Sosyal Bilimler Enstitüsü. 
Köse, A. (2006). Sekülerleşme Teorileri Bağlamında Türkiye'de Din ve Modernleşme. A. Köse (Ed.). Laik Ama Kutsal içinde. İstanbul: Etkileşim Yayınları, 2006, 11-19.

Köse, A.ve Ayten A. (2012). Din Psikolojisi. İstanbul: Timaş Yayınları.

Kula, M. N. (1986). Ergenlerde Kimlik Bunalımı ve Din Eğitiminin Etkisi. Yayımlanmamış yüksek lisans tezi. Bursa: Uludağ Üniversitesi Sosyal Bilimler Enstitüsü.

Kula, N. (2002). Gençlik Döneminde Kimlik ve Din. H. Hökelekli (Ed.). Gençlik Din ve Değerler Psikolojisi içinde. Ankara: Ankara Okulu Yayınları, 2002, 31-70.

Kurt, A. (2009a). Isş Adamlarında Dindarlık ve Dünyevileşme. Bursa: Emin Yayınları.

Kurt, A. (2009b). Dindarlığ Etkileyen Faktörler. Uludă̆ Üniversitesi İlahiyat Fakültesi Dergisi. 18 (2), 1-26.

Kurt, İ. (2014). Kültür ve Kültür Kuramları. M. Talas (Ed.). Sosyal Antropoloji içinde. İstanbul: Lisans Yayıncilık, 2014, 48-60.

Kurtaran, M. (2011). Farabi’nin Ahlak Felsefesi. Yayınlanmamış Yüksek Lisans Tezi. Ankara: Ankara Üniversitesi Sosyal Bilimler Enstitüsü.

Lasch, C. (2006). Narsizim Kültürü. Ü. H. Yolsal ve Suzan Ö. (çev.). Ankara: Bilim ve Sanat Yayınları.

Leger, D. H. (2004). Sekülerleşme, Gelenek ve Dindarlığın Yeni Şekilleri: Bazı Teorik Öneriler. H. Aydınalp (çev.), Marmara Üniversitesi İlahiyat Fakültesi Dergisi. Sayı:26, 45-58.

Lerner, D. (1964). The Passing of Traditional Society. New York: The Free Press of Glencoe.

Lerner, D. (1980). Çağdaşlaşma sürecinde iletişimin işlevi. N. Avcı (çev.). Anadolu Üniversitesi İletişim Bilimleri Fakültesi Uluslararası Hakemli İletişim Dergisi. Sayı: 3, 109134.

Luckmann, T. (2015). Görünmeyen Din. A. Coşkun, F. Aydın ve O. Coşkun (çev.). İstanbul: Rağbet Yayınları.

Marcuse, H. (2010). Tek Boyutlu İnsan. A. Yardımlı (çev.). İstanbul: İdea Yayınevi.

Mardin, Ş. (2004). Türkiye’de Din ve Siyaset. İstanbul: İletişim Yayınları.

Mardin, Ş. (2015). Türk Modernleşmesi. İstanbul: İletişim Yayınları.

Marshall, G. (2005). Sosyoloji Sözlüğ̈̈u. O. Akınhay ve D. Kömürcü (çev.). Ankara: Bilim ve Sanat Yayınları

Marx, K. (1979). Ekonomi Politiğin Eleştirisine Katkı. S. Belli (çev.), Ankara: Sol Yayınları. Marx, K. (1992a). Early Writting, Penguin Books.

Marx, K. (1997). Hegel'in Hukuk Felsefesinin Eleştirisine Katkı. Ankara: Sol Yayınları.

Marx, K. (2003). Kapital I. Cilt, Eriş Yayınları.

Marx, K. ve Engels F. (2007). Din Sosyolojisi. M. Yıldız (çev.), Ankara: Vadi Yayınları.

Marx, K.ve Engels F. (1992b). Alman İdeolojisi. Ankara: Sol Yayınları.

Memedoğlu, A. U. (2004). Kişilik ve Din. İstanbul: Değerler Eğitimi Merkezi Yayınları.

Mercan, Ç. S. (2010). Gelişim Psikolojisinde Kuramlar ve Araştırma Yöntemleri. H. Ergin ve A. Yıldız (Ed.). Gelişim Psikolojisi içinde. Ankara: Nobel Yayınları, 2010, 7-32.

Mill, J. S. (2019). Faydacılık. İstanbul: Pinhan Yayıncılık.

Moore, G. E. (1988). Principia Ethica. New York: Prometheus Books

Ok, Ü. (2011). Dini Tutum Ölçeği: Ölçek Geliştirme ve Geçerlilik Çalışması. Uluslararası İnsan Bilimleri Dergisi. Cilt:8, Sayı:2, 528-549.

Okumuş, E. (2013). Sosyolojinin Din Sorunsalı. M. Bayyiğit (Ed.). Din Sosyolojisi içinde. Konya: Palet Yayınları, 2013, 77-104. 
Onay, A. (2003). Mezun Oldukları Liselere Göre Üniversite Öğrencilerinin Dindarlık Düzeyleri Diyanet İşleri Başkanlığg Hizmetlerine ve Dini Gruplara Yönelimleri. Değerler Ĕ̆itimi Dergisi. 1 (1), 171-194.

Özgen, M. K. (1997). Farabide Mutluluk ve Ahlak İlişkisi. İstanbul: İnsan Yayınları.

Peker, H. (2019). Din Psikolojisi. İstanbul: Çamlıca Yayınları.

Polater, K. (2003). Kur’an’ı Kerim’e Göre Heva Kavramı ve Delaletteki Rolü. Atatürk Üniversitesi İlahiyat Fakültesi Dergisi. Sayı: 20, 261-299.

Polomo, M. (2011). Çă̆daş Sosyoloji Kuramları. Erbaş H. (çev.). Ankara: Palme Yayıncrlik.

Punch, K. F. (2011). Sosyal Araştırmalara Giriş, Nicel ve Nitel Yaklaşımlar. Ankara: Siyasal Kitapevi.

Razi, E. (2018). Ruh Sağlı̆̆ı. H. Karaman (çev.), İstanbul: İz Yayınları.

Riis, O. (2015). Modern Toplumda Din Araştırmaları Alanındaki Son Gelişmeler. M. A. Kirman ve İ. Çapçığlu (Ed.). Sekülerleşme Klasik ve Çağdaş Yaklaşımlar içinde. Ankara: Otto, 2015, 355-374.

Santrock, J. W. (2019). Yaşam Boyu Gelişim: Gelişim Psikolojisi. G. Yüksel (çev.), Ankara: Nobel Yayınları.

SEKAM. (2016). Türkiye’de Gençlik: Gençliği Özellikleri, Sorunları, Kimlikleri ve Beklentileri. İstanbul. (http://sekam.com.tr/images/resimler/468b1dd1.pdf)

Slattery, M. (2012). Sosyolojide Temel Fikirler. Ankara: Sentez Yayıncılık.

Stroll, A., Long, A. A., Bourke, V. J. \& Campbell, R. (2017). Etik kuramları. M. Türkeli (çev.), Ankara: Lotus Yayınevi.

Sunar, C. (1967). İslam Felsefesi Dersleri. Ankara: Ankara Üniversitesi Basımevi.

Şenel, Cahid. (2013). İbn Miskeveyh: Yeni Eflatuncu Metafizik ve Ahlak. M. C. Kaya (Ed.). İslam Felsefesi Tarih ve Problemleri içinde. İstanbul: İsam Yayınları, 2013, 221249.

Şentürk, R. (2004). Yeni Din Sosyolojileri. İstanbul: İz Yayınları.

Taş, K. (2013). Sosyolojik Din Tanımları. N. Akyüz ve İ. Çapçığlu (Ed.). Din Sosyolojisi içinde. Ankara: Grafiker Yayınları, 2013, 37-42.

Taylan, N. (1991). Ana Hatlarıla İslam Felsefesi, Kaynaklart-Temsilcileri Tesirleri, İstanbul: Ensar Neşriyat.

TGSP. (2018). Türkiye’nin Gençleri. İstanbul.

Tilley, J. J. (2012). Hedonism, Encyclopedia of Applied Ethics. San Diego: Academic Press, 566-573.

Tischler, H. L. (1996). Introduction To Sociology. Florida: The Harcourt Press.

Torlak, Ö. (2000). Tüketim; Bireysel Eylemin Toplumsal Dönüşümü. Ankara: İnkılab Yayınevi.

TÜİK (2018). Gençlik İstatistikleri Raporu. Ankara.

Tümer, G. (1986). Çeşitli Yönleriyle Din. Ankara Üniversitesi İlahiyat Fakültesi Dergisi. Cilt: 28, 213-267.

Türkdoğan, O. (2008). Osmanlidan Günümüze Türk Toplum Yapısı. İstanbul: Timaş Yayinlar1.

Türkeri, M. (2003). Bazı Ahlak Teorileri Açısından Fahrettin Razi’nin Ahlak Anlayışı. D. E. Ü. İlahiyat Fakültesi Dergisi. Sayı: 17, 63-89.

Türkeri, Ö. (2006). Nefis. TDV İslam Ansiklopedisi. Cilt:32, Ankara: Türkiye Diyanet Vakfı Yayınları. 
Uludağ, S. 2006). Nefis. TDV İslam Ansiklopedisi. Cilt:32, Ankara: Türkiye Diyanet Vakfı Yayınları.

Ulusoy, D. M. (2018). Sosyalleşme. E. Sağlam, A. Boyacığlu ve A. Bakacak (ed). Sosyoloji içinde. Ankara: Siyasal Kitapevi, 2018, 158-180.

Uysal, V. (1996). Din Psikolojisi Açısından Dini Tutum, Davranışve Şahsiyet Özellikleri. İstanbul: Marmara Üniversitesi İlahiyat Vakfı Yayınları.

Uysal, V. (2003). Türkiye’de Dindarlık ve Kadın. İstanbul: Çamlıca Yayınları.

Ülken, H. Z. (1958). Felsefeye Giriş, İkinci Kısım. Ankara: AÜİF Yayınları.

Ünal, M. (2007). Modern Toplumda Dinsel Bireycilik. Yayımlanmış Doktora Tezi. İzmir: Dokuz Eylül Üniversitesi Sosyal Bilimler Enstitüsü.

Vatandaş, C. (2007). Toplumsal Cinsiyet ve Cinsiyet Rollerinin Algılanışı. Sosyoloji Konferansları Dergisi. Sayı:35, 29-55.

Veblen, T. (2005). Aylak Sınıfın Teorisi. Z. Gültekin ve C. Atay (çev.). İstanbul: Babil Yayinlari.

Vural, M. (2018). İslam Ahlakı ve Modern Ahlak Felsefelerine Eleştirel Bir Bakıș. M. S. Saruhan (Ed.). İslam Ahlak Esasları ve Felsefesi içinde. Ankara: Grafiker Yayınları, 2018, 345-381.

Wallerstein, I. (2006). Tarihsel Kapitalizm. N. Alpay (çev). İstanbul: Metis Yayıncılık.

Weber, M. (2003). Sosyoloji Yazıları. T. Parlak (çev). İstanbul: İletişim Yayınları.

Weber, M. (2011). Protestan Ahlakı ve Kapitalizmin Ruhu. M. Köktürk (çev.). Ankara: Bilgesu Yayıncilik.

Weber, M. (2012). Din Sosyolojisi. L. Boyacı (çev.). İstanbul: Yarın Yayınları

Weijers, D. M. (2012). Hedonism and Happiness in Theory and Practice. Yayınlanmamış Doktora Tezi. Yeni Zelanda: Victoria University of Wellington.

Wilson, B. (2015). Sekülerleşme. A. Bayer (çev.). M. A. Kirman ve İ. Çapçıŏlu (Ed.). Sekülerleşme Klasik ve Çağdaş Yaklaşımlar içinde. Ankara: Otto, 2015, 9-24.

Yapıcı, A. (2006). Yeni Bir Dindarlık Ölçeği ve Üniversiteli Gençlerin Dinin Etkisini Hissetme Düzeyi: Çukurova Üniversitesi Örneği. Çukurova Üniversitesi İlahiyat Fakültesi Dergisi. Y1l: 6 say1: 1, 65-115.

Yapıcı, A. (2018). Küreselleşen Dünyada Gençlik ve Gençlerde Dini Hayat. E. Erdem ve H. Şahin (Ed.). Peygamber ve Gençlik içinde. Ankara: Diyanet İşleri Başkanlığı Yayınlar1, 2018, 83-100.

Yazır, E. (1979). Hak Dini Kur'an Dili, Cilt 1. İstanbul: Eser Neşriyat.

Yıldız, A. (2019). Hedonist Değer Anlayışının Eleştirisi. Sakarya Üniversitesi İlahiyat Fakültesi Dergisi. Cilt: 21, Say1: 40, 324-348.

Yılmaz, G. (2019). Gaziosmanpaşa Üniversitesi Tip Fakültesi Öğrencilerinde İnternet Bağımlılığı Yaygınlığı, İnternet Bağımlılığının Öğrencilerin Depresyon Düzeyi ve Sosyodemografik Özellikleri ile İlişkisi. Yayınlanmamış Tipta Uzmanlık Tezi. Tokat: Gaziosmanpaşa Üniversitesi Tip Fakültesi. 


\section{Özgeçmiş}

Ankara’da doğan yazar, evli ve bir çocuk annesidir. Yazar lisans eğitimini Hacettepe Üniversitesi Sosyoloji bölümünde, yüksek lisans eğitimini Ankara Yıldırım Beyazıd Üniversitesi Felsefe ve Din Bilimleri/Din Sosyolojisi alanında ve doktorasını Marmara Üniversitesi Felsefe ve Din Bilimleri/Din Sosyolojisi alanında tamamladı. 2016 yılından bu yana İstanbul Aydın Üniversitesi Fen Edebiyat Fakültesi Sosyoloji Bölümünde araştırma görevlisi doktor olarak çalışmaktadır. Çeşitli kongrede bildirileri ve makaleleri bulunan yazarın, din sosyolojisi, sekülerleşme, çalışma ahlakı ve gençlik sosyolojisi gibi alanlar ilgilendiği konular arasindadir.

Dr. Fatma Nur ŞENGÜL 